\title{
PENAPISAN FITOKIMIA DAN ANALISIS KADAR FLAVONOID TOTAL RIMPANG TEMU MANGGA (Curcuma mangga Valeton \& Zijp.) DENGAN PERBEDAAN POLARITAS PELARUT
}

\author{
Dwi Susiloningrum ${ }^{1}$, Dania Indrawati ${ }^{2}$ \\ 1-2 Program Studi S-1 Farmasi, Stikes Cendekia Utama Kudus \\ Email: dsusiloningrum@gmail.com
}

\begin{abstract}
ABSTRAK
Rimpang temu mangga merupakan salah satu tanaman keluarga Zingeberaceae. Rimpang ini banyak ditemukan di Indonesia dan digunakan sebagai tanaman obat. Salah satu metabolit dalam tanaman ini adalah flavonoid. Tujuan Penelitian ini untuk mengetahui metabolit sekunder dan kadar flavonoid dari rimpang temu mangga dengan perbedaan polaritas pelarut. Penelitian ini adalah penelitian eksperimental. Rimpang temu mangga diekstraksi dengan cara maserasi menggunakan pelarut etanol $80 \%$ dan etil asetat. Ekstrak etanol $80 \%$ dan ekstrak etil asetat dilakukan pengujian kandungan metabolit sekunder dengan cara penapisan fitokimia metode tabung dan kromatografi lapis tipis (KLT). Penentuan kadar flavonoid total menggunakan metode spektrofotometri UV-Vis. Data dianalisis menggunakan uji normalitas data ShapiroWilk dan homogenitas dan dilanjutkan uji independent sample t-test. Hasil Penapisan fitokimia metode tabung ekstrak etanol $80 \%$ dan ekstrak etil asetat mengandung flavonoid, tanin, saponin, dan alkaloid. Analisis kromatografi lapis tipis pada ekstrak etanol $80 \%$ dan ekstrak etil asetat mengandung flavonoid yaitu timbulnya bercak noda berwarna kuning dengan nilai $\mathrm{Rf}$ berturut-turut yaitu 0,68 dan 0,7. Berdasarkan uji independent sample t test tidak ada perbedaan bermakna pada kadar flavonoid total ekstrak etanol $80 \%$ dan ekstrak etil asetat yaitu $65,77 \% \pm$ 2,21 dan $60,92 \% \pm 4,55$.
\end{abstract}

Kata Kunci: Rimpang temu mangga (Curcuma mangga Valeton \& Zijp.), Kadar Flavonoid Total, etanol, etil asetat

\section{ABSTRACT}

Temu mangga rhizome is a plant of the Zingeberaceae family. This rhizome is found in Indonesia and is used as a medicinal plant. One of the metabolites in this plant are flavonoids. The purpose of this study was to determine the secondary metabolites and levels of flavonoids from the temu mangga rhizome with difference in polarity of the solvent. This research is an experimental research. Temu mango rhizome was extracted by maceration using ethanol $80 \%$ and ethyl acetate as solvent. The $80 \%$ ethanol extract and ethyl acetate extract were tested for secondary metabolite content by means of phytochemical screening using tube method and thin layer chromatography (TLC). Determination of total flavonoid levels using the UV-Vis spectrophotometric method. The data were analyzed using the Shapiro-Wilk data normality test 
and homogeneity and continued with the independent sample t-test. Results Phytochemical screening by tube method of $80 \%$ ethanol extract and ethyl acetate extract contained flavonoids, tannins, saponins, and alkaloids. Thin layer chromatography analysis of $80 \%$ ethanol extract and ethyl acetate extract contained flavonoids, namely the appearance of yellow stains with $R f$ values of 0.68 and 0.7 , respectively. Based on the independent sample $t$ test, there was no significant difference in the total flavonoid levels of $80 \%$ ethanol extract and ethyl acetate extract, namely $65.77 \% \pm 2.21$ and $60.92 \% \pm 4.55$.

Keywords: Curcuma mangga Valeton \& Zijp, total flavonoids, ethanol, ethyl acetat

\section{LATAR BELAKANG}

Tanaman obat adalah tanaman yang salah satu atau seluruh bagiannya mengandung senyawa aktif yang dapat bermanfaat bagi kesehatan tubuh. Tanaman obat dapat digunakan dalam pencegahan maupun pengobatan penyakit. Bagian tanaman yang sering digunakan yaitu daun, buah, bunga, akar, rimpang, batang (kulit) dan getah atau resin (Sada, 2010). Salah satu tanaman obat yang ada di Indonesia adalah rimpang temu mangga.

Rimpang temu mangga (Curcuma mangga Valeton \&Zijp) merupakan salah satu keluarga Zingeberaceae dan memiliki kandungan metabolit sekunder seperti flavonoid ((Madihah, Alfina, dan Gani, 2016).

Flavonoid mempunyai 15 atom karbon dengan cincin benzen (C6) yang tertarik dengan rantai propana (C3) sehingga terbentuk susunan rantai C6-C3-C6. Berdasarkan penelitian Marliani, Budiana, \& Anandari (2017) menjelaskan bahwa penggunaan pelarut berpengaruh terhadap kadar flavonoid yang diperoleh dari proses ekstraksi.

Flavonoid merupakan metabolit sekunder yang bersifat polar karena tersebar luas pada tumbuhan yang berbentuk glikosida dan berikatan dengan gula. Metabolit sekunder ini dapat larut dalam pelarut polar seperti etanol, air, metanol, serta pelarut semi polar seperti etil asetat, maupun campuran pelarut tersebut yang dapat digunakan untuk menarik senyawa flavonoid dari tanaman tersebut (Ekawati dan Suirta, 2017). Sebaliknya, flavonoid juga mempunyai aglikon yang bersifat kurang polar seperti isoflavon, flavanon, flavon, serta flavonon yang cenderung lebih mudah larut dalam pelarut seperti eter dan kloroform (Markham, 1988).

Metabolit sekunder dalam tumbuhan dapat diperoleh dengan cara ekstraksi. Faktor yang harus diperhatikan dalam proses ekstraksi salah satunya yaitu pemilihan pelarut yang harus sesuai dengan polaritas suatu senyawa. Berdasarkan kepolarannya pelarut dibagi menjadi tiga yaitu pelarut polar, semi polar, dan non polar (Suryani \& Permana, 2015). Hal ini sesuai dengan prinsip like dissolve like dimana senyawa yang bersifat polar akan larut dalam pelarut polar dan senyawa yang bersifat non polar akan larut dalam pelarut non polar (Arifianti, Oktarina, \& Kusumawati, 2014). Berdasarkan hal tersebut, maka dilakukan penapisan fitokimia dengan metode tabung dan KLT (Kromatografi Lapis Tipis) dan analisis kadar flavonoid total rimpang temu mangga dengan perbedaan polaritas pelarut yaitu etanol $80 \%$ dan etil asetat. 


\section{METODE PENELITIAN}

\section{Jenis Penelitian}

Dalam penelitian ini digunakan penelitian eksperimental secara deskriptif kuantitatif yaitu penetapan kadar flavonoid total dari ekstrak etanol $80 \%$ dan ekstrak etil asetat rimpang temu mangga (Curcuma mangga Valeton \& Zijp.) dan penapisan fitokimia.

\section{Populasi dan Sampel Penelitian}

Sampel yang digunakan dalam penelitian ini adalah ekstrak rimpang temu mangga (Curcuma mangga Valeton \& Zijp.) yang diambil di Dukuh Kandangmas, desa Masin, kecamatan Dawe, kabupaten Kudus.

\section{Alat dan Bahan}

Alat yang digunakan untuk ekstraksi yaitu neraca analitik (Ohaus), botol kaca (gelap), blender, ayakan 44 mesh, kertas saring (whatman-50), corong, gelas ukur, erlenmeyer, water bath (DHH-4), cawan porselin, sudip. Alat yang digunakan untuk skrining fitokimia yaitu tabung reaksi, rak tabung, penjepit tabung, pipet tetes, penangas air. Alat yang digunakan untuk KLT antara lain Plat KLT $\left(\mathrm{G}_{60} \mathrm{~F}_{254}\right)$, great chamber, pipa kapiler, Lampu UV $254 \mathrm{~nm}$. Alat yang digunakan untuk penetapan kadar flavonoid total yaitu neraca analitik (Ohaus), spektrofotometri Visibel (Biobase), labu ukur (herma), beaker glass, pipet volume, mikro pipet (scilogex).

Bahan yang digunakn untuk ekstraksi antara lain rimpang temu mangga (Curcuma mangga Valeton \& Zijp.), etanol $80 \%$, etil asetat. Bahan untuk skrining fitokimia terdiri dari ekstrak rimpang temu mangga (Curcuma mangga Val), serbuk magnesium, $\mathrm{HCl}$ pekat, $\mathrm{NaOH} 10 \%$, air panas, $\mathrm{FeCl}_{3} 1 \%, \mathrm{HCl} 2 \mathrm{~N}$, pereaksi mayer, pereaksi dragendorf, pereaksi wegner. Bahan yang digunakan untuk kromatografi lapis tipis yaitu ekstrak rimpang temu mangga (Curcuma mangga Valeton \& Zijp.), pengembang metanol dan kloroform, uap amoniak. Bahan untuk penetapan kadar flavonoid total terdiri dari ekstrak rimpang temu mangga (Curcuma mangga Valeton \& Zijp.), larutan baku kuersetin, etanol p.a, $\mathrm{AlCl}_{3} 2 \%$, natrium asetat $1 \mathrm{M}$, aquadest

\section{Pelaksanaan Percobaan}

Penelitian ini menggunakan rimpang temu mangga (Curcuma mangga Valeton \& Zijp.) yang selanjutnya akan dilakukan sortasi basah untuk memisahkan kotoran atau benda asing pada tanaman sebelum dilakukan pencucian. Pengeringan pada penelitian ini dilakukan dengan cara diangin-anginkan atau sinar matahari tidak langsung (ditutup kain hitam). Proses selanjutnya setelah diperoleh simplisia kering yaitu dilakukan penyerbukan dengan cara diblender. Serbuk simplisia diayak menggunakan ayakan no 44 mesh, adapun tujuan dari pengayakan yaitu untuk menyeragamkan ukuran serbuk.

Hasil serbuk rimpang temu mangga (Curcuma mangga Valeton \& Zijp.) kemudian ditimbang $200 \mathrm{mg}$ untuk masing-masing pelarut yaitu etanol $80 \%$ dan etil asetat untuk selanjutnya dilakukan ekstraksi.

Metode Ekstraksi dalam penelitian ini menggunakan metode maserasi. Serbuk rimpang temu mangga (Curcuma mangga Valeton \& Zijp.) diekstraksi menggunakan variasi pelarut yaitu etanol $80 \%$ dan etil asetat. Proses maserasi dalam penelitian ini dilakukan dengan dengan menggunakan perbandingan 1:6 (200 mg dalam $1200 \mathrm{~mL}$ pelarut).

Sampel direndam dalam wadah kaca yang tertutup rapat dan terhindar dari cahaya dan didiamkan selama 24 jam dengan sesekali dilakukan pengadukan, kemudian dilakukan penyaringan untuk memisahkan filtrat dan residu. Residu yang dihasilkan 
diremaserasi dengan pelarut dan jumlah yang sama sampai diperoleh larutan yang jernih. Proses maserasi dalam penelitian ini dilakukan selama 3 × 24 jam yang ditandai dengan larutan menjadi jernih. Selanjutnya dilakukan penapisan fitokimia.

\section{Penapisan Fitokimia}

Penapisan fitokimia yang digunakan dalam penelitian ini adalah metode tabung dan KLT.

\section{Identifikasi flavonoid dengan metode tabung}

Sebanyak $0,1 \mathrm{~g}$ ekstrak dipanaskan dengan $5 \mathrm{~mL}$ aquadest selama 5 menit, kemudian dibagi menjadi 3 tabung reaksi dan dilakukan uji :

a. Uji Wilstater

Filtrat sebanyak $1 \mathrm{~mL}$ ditambahkan dengan serbuk magnesium dan 2 tetes $\mathrm{HCl}$ pekat selanjutnya dikocok. Perubahan yang nampak yaitu terbentuk warna jingga menandakan adanya senyawa flavon, sedangkan jika terbentuk warna merah tua menunjukkan adanya senyawa flavonol (Marliana, Suyanti, \& Suyono,. 2005).

b. Uji Bate-Smith

Filtrat sebanyak $1 \mathrm{~mL}$ kemudian ditambahkan dengan $\mathrm{HCl}$ pekat beberapa tetes, setelah itu dipanaskan diatas penangas. Perubahan warna yang terjadi pada sampel yaitu merah tua sampai ungu (Marliana, Suyanti, \& Suyono, 2005). Terbentuknya warna merah tua sampai ungu menunjukkan adanya flavonoid jenis antosianidin (Rahayu, Kurniasih, \& Amalia, 2015).

c. $\mathrm{Uji} \mathrm{NaOH} 10 \%$

Filtrat sebanyak $1 \mathrm{~mL}$ ditambahkan dengan larutan $\mathrm{NaOH} 10 \%$ beberapa tetes sampai terjadi perubahan warna (Harborne, 1996). Perubahan warna yang terjadi menunjukkan adanya senyawa fenol (Rahayu, Kurniasih, \& Amalia, 2015).

\section{Identifikasi flavonoid dengan metode KLT}

Fase diam yang digunakan yaitu plat silika gel $\mathrm{G}_{60} \mathrm{~F}_{254}$ dan fase gerak kloroform : metanol $(14: 1) \mathrm{v} / \mathrm{v}$. Ekstrak ditotolkan pada plat silika gel $\mathrm{G}_{60} \mathrm{~F}_{254}$ yang sebelumnya sudah diaktifasi pada suhu $100{ }^{\circ} \mathrm{C}$ selama 1 jam, kemudian plat dimasukkan dalam chamber berisikan fase gerak yang sudah jenuh. Noda yang terbentuk pada plat silika di amati dibawah sinar UV pada panjang gelombang $254 \mathrm{~nm}$ dan di uap dengan penampak noda yaitu amoniak.

$$
\mathrm{Rf}=\frac{\text { Jarak senyawa yang terelusi }}{\text { Jarak senyawa yang mengelusi }}
$$

\section{Analisis Kadar Flavonoid total \\ Pembuatan larutan baku kuersetin}

Kuersetin ditimbang sebanyak $100 \mathrm{mg}$ dan dilarutkan dalam 100,0 mL etanol p.a sebagai larutan induk kuersetin 1000 ppm. Larutan induk tersebut diencerkan menjadi konsentrasi $100 \mathrm{ppm}$ sehingga diperoleh larutan stok kuersetin. Larutan stok dibuat pengenceran dengan seri konsentrasi 40, 60, 80, dan $100 \mathrm{ppm}$. Larutan standart kuersetin sebanyak $0,1 \mathrm{~mL}$ ditambahkan $0,1 \mathrm{~mL}$ aluminium (III) klorida $2 \%, 0,1 \mathrm{~mL}$ natrium asetat $1 \mathrm{M}$ dan $2 \mathrm{~mL}$ etanol p.a kemudian diinkubasi selama 30 menit. 


\section{Penentuan panjang gelombang maksimum kuersetin}

Salah satu seri pengenceran larutan standar kuersetin konsentrasi 60 ppm yang telah di inkubasi selama 30 menit di ukur serapannya pada panjang gelombang 400-500 $\mathrm{nm}$. Panjang gelombang yang menunjukkan serapan tertinggi disebut panjang gelombang maksimum.

\section{Penentuan operating time}

Penentuan operating time dilakukan pada larutan kuersetin konsentrasi 60 ppm, diamati absorbansinya pada panjang gelombang maksimum yang telah diperoleh dengan interval waktu 2 menit selama 60 menit sampai diperoleh absorbansi yang stabil.

\section{Penentuan Kurva Baku Kuersetin}

Panjang gelombang maksimum yang diperoleh selanjutnya dilakukan penentuan kurva baku kersetin. Larutan standar 40, 60, 80 dan 100 ppm dipipet sebanyak 0,1 mL dimasukkan ke dalam labu ukur $10 \mathrm{~mL}$. Larutan standar ditambahkan $0,1 \mathrm{~mL}$ aluminium klorida $2 \%, 0,1 \mathrm{~mL}$ natrium asetat $1 \mathrm{M}$ dan ditambahkan etanol p.a $2 \mathrm{~mL}$, dikocok sampai homogen. Larutan di inkubasi pada suhu kamar dan di diamkan susuai dengan waktu stabil yang diperoleh dari operating time. Larutan standar kuersetin diukur serapannya, kemudian dihubungkan antara konsentrasi larutan standar kuersetin dengan hasil serapannya pada panjang gelombang maksimum sehingga diperoleh persamaan regresi linier.

\section{Penentuan Kadar Flavonoid Total}

Larutan sampel 100 ppm dipipet sebanyak $0,1 \mathrm{~mL}$, dimasukkan ke dalam labu ukur $10 \mathrm{~mL}$, ditambahkan $0,1 \mathrm{~mL}$ aluminium (III) klorida $2 \%, 0,1 \mathrm{~mL}$ natrium asetat 1 $\mathrm{M}$ dan ditambahkan etanol p.a $2 \mathrm{~mL}$, di gojok sampai homogen. Larutan sampel diinkubasi pada suhu kamar sesuai yang diperoleh dari hasil operating time. Pengukuran serapan dilakukan menggunakan spektrofotometri visibel pada panjang gelombang maksimum. Replikasi dilakukan sebanyak tiga kali (Chang et al., 2002) .

$$
\begin{aligned}
& \text { Rumus penentuan kadar flavonoid total (\%) } \\
& \qquad \begin{array}{l}
\mathrm{F}=\frac{\mathrm{C} \times \mathrm{V} \times \mathrm{Fp}}{\mathrm{m}} \times 100 \% \\
\text { Keterangan : } \\
\mathrm{C}=\text { Konsentrasi kuersetin }(\mathrm{ppm} \text { atau } \mathrm{mg} / 1000 \mathrm{~mL}) \\
\mathrm{V}=\text { Volume total ekstrak }(\mathrm{mL}) \\
\mathrm{Fp}=\text { Faktor pengenceran } \\
\mathrm{m}=\text { Berat Sampel }(\mathrm{mg})
\end{array}
\end{aligned}
$$

\section{HASIL DAN PEMBAHASAN}

Metode Ekstraksi dalam penelitian ini menggunakan metode maserasi. Pemilihan penggunaan metode maserasi karena metode sederhana, mudah dan tanpa melalui proses pemanasan (Kusuma et al., 2011). Metode ini cocok untuk metabolit sekunder yang tidak tahan panas seperti flavonoid, karena dilakukan tanpa melalui proses pemanasan sehingga kemungkinan rusaknya komponen bahan aktif dalam sampel dapat dihindari (Salmia, 2016). 
Penelitian ini menggunakan variasi polaritas pelarut etanol dan etil asetat. Pemilihan cairan penyari (pelarut) merupakan faktor penting dalam sebuah ekstraksi karena akan mempengaruhi jenis dan jumlah zat aktif yang terkandung dalam ekstrak. (Arifianti, Oktarina, \& Kusumawati 2014). Prinsip like dissolve like, dimana senyawa yang bersifat polar akan larut dalam pelarut polar dan senyawa yang bersifat non polar akan larut dalam pelarut non polar.

\section{Tabel 1}

Hasil ekstraksi etanol $80 \%$ dan ekstrak etil asetat rimpang temu mangga

\begin{tabular}{cccc}
\hline Sampel & $\begin{array}{c}\text { Serbuk } \\
(\mathrm{g})\end{array}$ & $\begin{array}{c}\text { Ekstrak } \\
(\mathrm{g})\end{array}$ & $\begin{array}{c}\text { Rendemen }(\% \\
\mathrm{b} / \mathrm{b})\end{array}$ \\
\hline Ekstrak Etanol 80\% & 200 & 23,42 & 11,71 \\
Ekstrak Etil Asetat & 200 & 20,19 & 10,09 \\
\hline
\end{tabular}

Hasil maserasi diperoleh ekstrak etanol $80 \%$ 23,42 gram dan ekstrak etil asetat 20,19 gram. Rendemen yang diperoleh dari masing-masing pelarut yaitu $11,71 \%$ dan $10,09 \%$. Penelitian ini rendemen yang diperoleh ekstrak etanol $80 \%$ lebih tinggi dibanding ekstrak etil asetat. Hal ini menunjukkan bahwa pelarut etanol $80 \%$ mampu mengekstraksi senyawa lebih baik, karena berdasarkan kesamaan sifat kepolaran anatara pelarut dengan senyawa. Penggunaan jenis pelarut dengan perbedaan polaritas dapat berpengaruh terhadap rendemen yang dihasilkan. Berdasarkan konstanta dielektrik suatu pelarut, semakin tinggi konstanta dielektriknya maka pelarut bersifat semakin polar. Konstanta dielektrik yang dimiliki etanol yaitu 30 sedangkan pada etil asetat yaitu 6,0 (Verdiana, Widawarta, \& Permana., 2018).

Tabel 2

Penapisan Fitokimia dengan Metode Tabung

\begin{tabular}{|c|c|c|c|}
\hline \multirow[b]{2}{*}{$\begin{array}{l}\text { Golongan } \\
\text { senyawa }\end{array}$} & \multirow[b]{2}{*}{ Pereaksi } & \multicolumn{2}{|l|}{ Keterangan } \\
\hline & & Pelarut etanol & $\begin{array}{l}\text { Pelarut etil } \\
\text { asetat }\end{array}$ \\
\hline \multirow[t]{3}{*}{ Flavonoid } & $\begin{array}{l}\text { Uji wilsataer : } \mathrm{Mg}+ \\
\mathrm{HCl} \text { Pekat }\end{array}$ & Jingga $\quad(+)$ & Jingga $\quad(+)$ \\
\hline & $\begin{array}{l}\text { Uji bate- Smith : } \mathrm{HCl} \\
\text { pekat + dipanaskan }\end{array}$ & Merah $\quad(+)$ & Merah \\
\hline & $\begin{array}{l}\text { Uji } \mathrm{NaOH} 10 \% \text { : } \\
\text { larutan } \mathrm{NaOH} 10 \% \\
\text { beberapa tetes }\end{array}$ & Oranye $\quad(+)$ & $\begin{array}{l}\text { Coklat } \\
\text { kehitaman }(+)\end{array}$ \\
\hline
\end{tabular}

Pengujian penapisan fitokimia ekstrak etanol $80 \%$ dan ekstrak etil asetat rimpang temu mangga (Curcuma mangga Valeton \& Zijp.) menunjukkan positif mengandung flavonoid yang dibuktikan dengan beberapa pengujian wilstater, batesmith dan $\mathrm{NaOH} 10 \%$.

Pada uji wilstater menunjukkan ektrak etanol $80 \%$ dan ekstrak etil asetat rimpang temu mangga (Curcuma mangga Valeton \& Zijp.) mengandung flavonoid yang ditandai dengan munculnya warna jingga. Hasil yang diperoleh tersebut sesuai dengan penelitian Rahayu, Kurniasih, \& Amalia, (2015) yang menyatakan bahwa terbentuknya warna jingga menunjukkan adanya flavonoid golongan flavonol dan flavanon.

Uji Bate-Smith dalam metode ini dilakukan dengan cara menambahkan larutan $\mathrm{HCl}$ pekat kemudian dilakukan pemanasan. Penambahan $\mathrm{HCl}$ pekat bertujuan untuk menghidrolisis dan memutus flavonoid menjadi aglikonnya, yaitu dengan menghidrolisis O-glikosil. O-glikosil akan tergantikan dengan $\mathrm{H}^{+}$dari asam, karena 
bersifat elektrofilik. Proses Pemanasan dilakukan untuk mempercepat reaksi hidrolisis (Estikawati \& Lindawati, 2019). Hasil fitokimia menunjukkan ekstrak etanol $80 \%$ dan ekstrak etil asetat rimpang temu mangga (Curcuma mangga Valeton \& Zijp.) mengandung flavonoid yang ditandai dengan munculnya warna merah. Hal ini sesuai dengan penelitian Rahayu, Kurniasih, \& Amalia (2015) bahwa terbentuknya warna merah menunjukkan flavonoid golongan antosianidin.

Uji NaoH 10\% Pengujian fitokimia ini dilakukan dengan menambahkan beberapa tetes $\mathrm{NaOH} 10 \%$ akan terjadi perubahan warna. Perubahan yang terjadi disebabkan karena pereaksi $\mathrm{NaOH} 10 \%$ merupakan katalis basa yang menyebabkan penguraian senyawa Kristin yang merupakan turunan dari senyawa flavon menjadi molekul asetofenon (Theodora, Gunawan, \& Swantara, 2019). Hasil penapisan fitokimia uji $\mathrm{NaOH} 10 \%$ menunjukkan ekstrak etanol $80 \%$ dan ekstrak etil asetat rimpang temu mangga (Curcuma mangga Valeton \& Zijp.) mengandung flavonoid yang ditunjukkan dengan perubahan warna yaitu coklat kehitaman dan orange. Hasil tersebut sesuai dengan penelitian Rahayu, Kurniasih, \& Amalia (2015) yang menyatakan bahwa terjadinya perubahan warna menunjukkan adanya flavonoid golongan senyawa fenol.

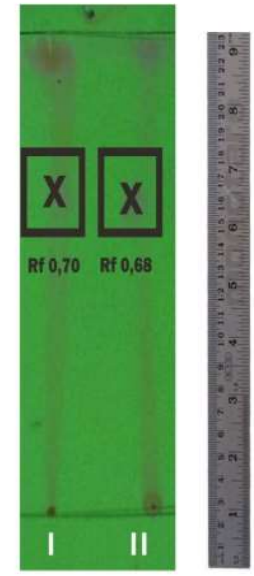

(A)

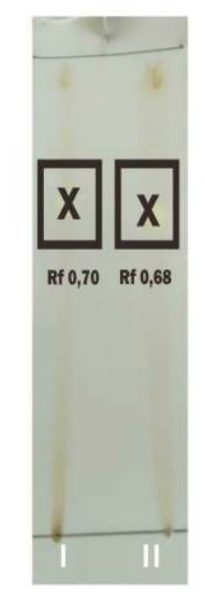

(B)

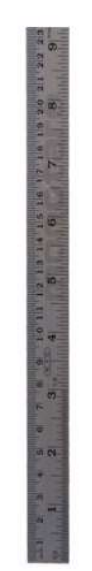

Gambar 1

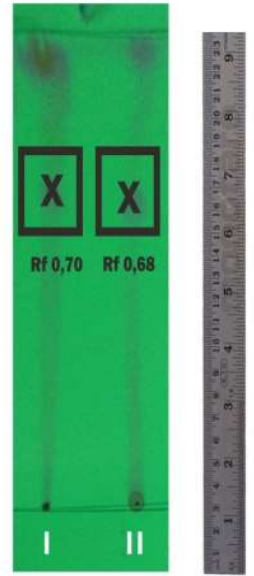

(C)

\section{Profil kromatogram ekstrak etil asetat (I) dan ekstrak etanol 80 \% (II) dengan fase diam silika $G_{60} F_{254}$ dan fase gerak kloroform : metanol (14:1). (A) UV 254 nm; (B) Uap amoniak; (C) Setelah diuap amoniak diamati dibawah UV $254 \mathbf{n m}$.}

Penapisan fitokimia menggunakkan metode KLT yaitu untuk mempertegas hasil yang didapat dari penapisan fitokimia dengan metode tabung. Fase diam yang digunakan yaitu plat silika gel $\mathrm{G}_{60} \mathrm{~F}_{254}$ dan fase gerak kloroform : metanol (14:1). Ekstrak ditotolkan pada plat silika yang sebelumnya sudah diaktifasi pada suhu $100{ }^{\circ} \mathrm{C}$ selama 1 jam, kemudian plat dimasukkan dalam chamber berisikan fase gerak yang sudah jenuh. Tujuan dilakukannya aktivasi yaitu untuk menghilangkan kandungan air yang terdapat pada plat silika agar tidak mengganggu jalannya analisis (Fath, 2016).

Hasil dari pengujian flavonoid dengan metode KLT dapat dilihat pada gambar 1. Kromatogram yang timbul diamati dibawah sinar UV $254 \mathrm{~nm}$ dan diuapi amoniak. Bercak yang timbul setelah diuap dengan amoniak berwarna kuning muda dan bercak yang diamati dibawah sinar UV $254 \mathrm{~nm}$ dengan nilai Rf 0,68 untuk ekstrak etanol $80 \%$ dan 0,70 untuk ekstrak etil asetat. Hasil yang diperoleh sesuai dengan penelitian Marliana, Suyanti, \& Suyono (2005) setelah diuap dengan amoniak berwarna kuning 
muda sehingga menegaskan adanya kandungan flavonoid pada ekstrak etanol $80 \%$ dan ekstrak etil asetat rimpang temu mangga (Curcuma mangga Valeton \& Zijp.). Noda semakin jelas setelah diuapi dengan amoniak dengan terbentuknya warna kuning yang masuk rentang pada nilai Rf 0,2-0,75 sebagai flavonoid (Rahayu, Kurniasih, \& Amalia., 2015).

Tabel 3

Kandungan Flavonoid Total Ekstrak etanol 80 \% dan Ekstrak Etil Asetat Rimpang Temu Mangga (Curcuma mangga Valeton \& Zijp.)

\begin{tabular}{lllllll}
\hline Sampel & $\begin{array}{l}\text { Penimbangan } \\
\text { Bahan }(\mathrm{mg})\end{array}$ & Absorbansi & $\begin{array}{l}\text { Konsentrasi } \\
(\mathrm{ppm})\end{array}$ & $\begin{array}{l}\text { Kadar } \\
\text { Flavonoid } \\
(\%)\end{array}$ & $\begin{array}{l}\text { Rata- } \\
\text { rata } \\
(\%)\end{array}$ & SD \\
\hline Ekstrak & & 0,461 & 63,33 & 63,33 & & \\
Etanol & 10 & 0,479 & 65,33 & 66,33 & 65,77 & $\pm 2,21$ \\
$80 \%$ & & 0,500 & 67,66 & 67,66 & & \\
& & & & & & \\
Ekstrak & & 0,409 & 57,55 & 57,55 & & \\
Etil & 10 & 0,423 & 59,11 & 59,11 & 60,92 & $\pm 4,55$ \\
Asetat & & 0,468 & 66,11 & 66,11 & & \\
\hline
\end{tabular}

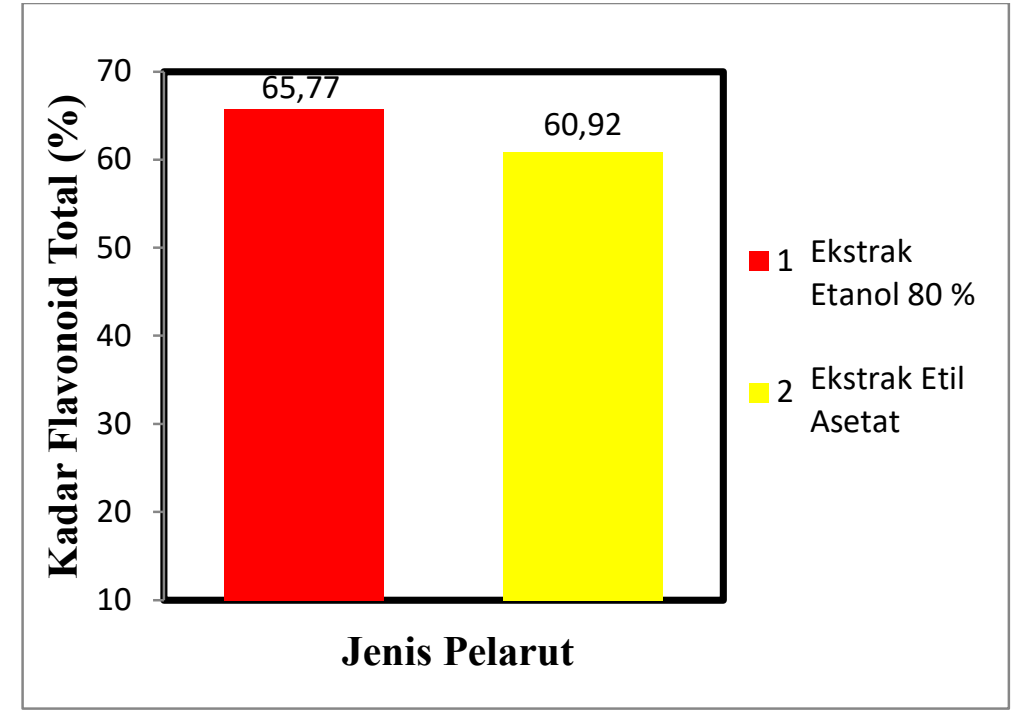

Gambar 2

Perbandingan Kadar Flavonoid Total Rimpang Temu Mangga (Curcuma mangga Valeton \& Zijp.) Berdasarkan Jenis Pelarut

Sebelum dilakukan penetapan kadar flavonoid total terlebih daulu menentukan panjang gelombang maksimum pada larutan standar. Panjang gelombang maksimum $(\lambda$ max) adalah panjang gelombang pada saat serapan maksimum dengan cara membaca serapan larutan standar. Tujuan dilakukan penetapan panjang gelombang maksimum yaitu untuk mengetahui besarnya serapan yang dibutuhkan larutan standar (Andriyani, Utami, \& Dhiani, 2010). Larutan standar yang digunakan dalam penelitian ini yaitu kuersetin. Pemilihan kuersetin sebagai larutan standar karena kuersetin merupakan flavonoid golongan flavonol yang mempunyai gugus keto pada $\mathrm{C}-4$ dan memiliki gugus hidroksi pada atom C-3 atau C-5 sehingga dapat membentuk kompleks warna dengan $\mathrm{AlCl}_{3}$ 
Panjang gelombang maksimum yang diperoleh dalam penelitian ini yaitu 444 $\mathrm{nm}$ dan operating time pada menit ke-37. Kadar flavonoid total pada ekstrak etanol 80 $\%$ yaitu $65,77 \%$ sedangkan pada ekstrak etil asetat yaitu $60,92 \%$. Kadar flavonoid total pada ekstrak etanol $80 \%$ lebih besar dibanding ekstrak etil asetat rimpang temu mangga (Curcuma mangga Valeton \& Zijp.). Hal ini dikarenakan senyawa flavonoid bersifat polar sehingga akan mudah larut dalam pelarut polar. Hasil ini sesuai dengan prinsip polarisasi, dimana suatu senyawa akan larut dalam pelarut yang mempunyai nilai kepolaran sama. Etanol mempunyai polaritas yang mendekati polaritas fenol dan flavonoid pada tanaman sehingga memiliki kemampuan sebagai pelarut yang baik dalam mengekstrak tanaman (Julianti, Irkawan, \& Iwansyah., 2019).

Tabel 4

Ringkasan Hasil Uji Independent Sample T-Test

\begin{tabular}{ccccc}
\hline \multirow{2}{*}{$\begin{array}{c}\text { Kelompok } \\
\text { Pelarut }\end{array}$} & $\begin{array}{c}\text { Uji } \\
\text { Normalitas } \\
\text { (Shapiro- } \\
\text { Wilk) }\end{array}$ & $\begin{array}{c}\text { Uji } \\
\text { Homogenitas }\end{array}$ & $\begin{array}{c}\text { Uji } \\
\text { Independent } \\
\text { Sampel T- } \\
\text { Test }\end{array}$ & Keterangan \\
\cline { 2 - 5 } & \multicolumn{4}{c}{ Sig. } \\
\hline $\begin{array}{c}\text { Etanol } \\
80 \%\end{array}$ & 0,916 & 0,355 & $\mathbf{0 , 0 9 1}$ & $>\mathbf{0 , 0 5}$ \\
Etil & 0,439 & 0,355 & $\mathbf{0 , 0 9 1}$ & $\mathbf{> 0 , 0 5}$ \\
Asetat & & & & \\
\hline
\end{tabular}

Keterangan :

Uji independent sample t-test : Nilai sig $>0,05$, artinya tidak ada perbedaan

Hasil uji independent sampel T-Test dapat dilihat pada kolom Equal Variances assumed nilai signifikansi yang ditunjukkan yaitu 0,091 yang artinya lebih besar dari 0,05 sehingga dapat disimpulkan bahwa nilai kadar flavonoid total antara ekstrak etanol $80 \%$ dan ekstrak etil asetat rimpang temu mangga (Curcuma mangga Valeton \& Zijp.) adalah sama atau tidak ada perbedaan yang signifikan.

Nilai kadar flavonoid dari pelarut etanol $80 \%$ dan etil asetat tidak ada perbedaan secara signifikan. Hal ini disebabkan karena pelarut etanol termasuk pelarut polar yang memiliki nilai kepolaran 5,5 sedangkan etil asetat yaitu 4,4. Berdasarkan nilai kepolaran pelarut tersebut tidak berbeda jauh antara etanol dan etil asetat sehingga kedua pelarut memiliki nilai kadar flavonoid total yang tidak berbeda jauh pula. Jenis flavonoid polar yaitu antosianin sedangkan flavonoid semi polar yaitu flavonoid O-glikosida (Kasminh., 2019).

\section{SIMPULAN DAN SARAN \\ Simpulan}

Berdasarkan hasil penelitian yang telah dilakukan, dapat di simpulkan sebagai berikut :

1. Kadar flavonoid total dari ekstrak etanol $80 \%$ dan ekstrak etil asetat rimpang temu mangga (Curcuma mangga Valeton \& Zijp.) yaitu 65,77 \% dan 60,92 \%.

2. Tidak ada perbedaan signifikan kadar flavonoid total rimpang temu mangga dengan pelarut etanol $80 \%$ dan etil asetat 


\section{Saran}

Perlu di lakukan pengujian pelarut etanol dengan berbagai konsentrasi sehingga di peroleh konsentrasi yang optimum untuk memperoleh kadar flavonoid total dari rimpang temu mangga.

\section{DAFTAR PUSTAKA}

Andriyani, D., Utami, P. I., \& Dhiani, B. A. (2010). Penetapan kadar tanin daun rambutan (Nephelium lappaceum.L) secara spektrofotometri ultraviolet visibel'. Jurnal Pharmacy, 7(2), 7.

Arifianti, L., Oktarina, R. D., \& Kusumawati, Idha. (2014). Pengaruh jenis pelarut pengektraksi terhadap kadar sinensetin dalam ekstrak daun Orthosiphon stamineus Benth. E-Journal Planta Husada, 2(1), 3.

Chang, C.-C., Yang, M.-H., Wen, H.-M., \& Chern, J.-C. (2002). 'Estimation of total flavonoid content in propolis by two complementary colorimetric methods'. Journal of Food and Drug Analysis, 10(3), 178.

Ekawati, M. A., \& Suirta, I. W. (2017). Isolasi dan identifikasi senyawa Flavonoid pada daun sembukan (Paederia foetida $L$ ) serta uji aktivitanya sebagai antioksidan. Jurnal Kimia, 11(1).44.

Fath, M. A. (2016). Profil kromatografi lapis tipis ekstrak etanol bji adas (Foeniculum vulgare Mill), rimpang kencur (Kaempferia galanga L.), rimpang kunyit putih (Curcuma zedoaria (Berg.) Roscoe), herba pegagan (Centella asiatica) serta ramuannya. Skripsi. Malang : Universitas Islam Negeri Maulana Malik Ibrahim.

Julianti, W. P., Ikrawan, Y., \& Iwansyah, A. C. (2019). Pengaruh jenis pelarut terhadap kandungan total fenolik, aktifitas antioksidan dan toksisitas ekstrak buah ciplukan (Physalis angulata L)'. Jurnal Riset Teknologi Industri, 13 (1), 70.

Kusuma, A. T., Adelah, A., Abidin, Z., \& Najib, A. (2011). Determination of Flavonoid Content of Ethyl Acetate Extract of Breadfruit Leaves (Artocarpus altilis). adDawaa'Jour.Pharm.Sci, 1(1), 7.

Madihah, Alfina, F., \& Gani, Y. Y. (2016). Kadar Glukosa Darah Dan Gambaran Histologis Pankreas Mencit (Mus musculus L.) Yang Diinduksi Aloksan Setela Perlakuan Ekstrak Rimpang Temu Mangga (Curcuma mangga Val.).Jurnal Biologi V, 20(2), 64.

Marliana, S. D., Suryanti, V., \& Suyono, S. (2005). The phytochemical screenings and thin layer chromatography analysis of chemical compounds in ethanol extract of labu siam fruit (Sechium edule Jacq. Swartz.)'. Biofarmasi Journal of Natural Product Biochemistry, 3(1), 26.

Marliani, L., Anandari, Y., \& Budiana, W. (2017). Pengaruh Pelarut, Waktu Dan Suhu Ekstraksi Terhadap Kandungan Senyawa. Ijpst, 4(2), 5

Rahayu, S., Kurniasih, N., \& Amalia, V. (2015). Ekstraksi Dan Identifikasi Senyawa Flavonoid dari Limbah Kulit Bawang Merah Sebagai Antioksidan Alami. Jurnalal Kimiya, 2(1),4.

Sada, J. T. (2010). 'Keragaman Tumbuhan Obat Tradisional di Kampung Nansfori Distrik Supiori Utara, Kabupaten Supiori-Papua'. Jurnal Biologi Papua, 2(2), 39. 
Salmia. (2016). Analisis Kadar Flavonoid Total Ekstrak Kulit Batang Kedondong Bangkok (Spondias dulcis) Dengan Metode Spektrofotometri UV-Vis. Skripsi. Makasar : Universitas Islam Negeri Alauddin Makasar.

Suryani, N. C., \& Permana, D. G. M. (2015). Pengaruh Jenis Pelarut Terhadap Kandungan Total Flavonoid dan Aktivitas Antioksidan Ekstrak Daun Matoa (Pometia pinnata). Skripsi. Bandung :Universitas Udayana Bndung.

Theodora, C. T., Gunawan, I. W. G., \& Swantara, I. M. D. (2019). Isolasi dan identifikasi golongan flavonoid pada ekstrak etil asetat daun gedi (Abelmoschus manihot L.)'. Jurnal Kimia, 13(2), 131.

Verdiana, M., Widarta, I. W. R., \& Permana, I. D. G. M. (2018). Pengaruh jenis pelarut pada ekstraki menggunakan gelombang ultrasonik terhadap aktivitas antioksidan ekstrak kulit buah lemon (Citrus limon (Linn.) Burm F.). Jurnal Ilmu dan Teknologi Pangan (ITEPA), 7(4), 213 